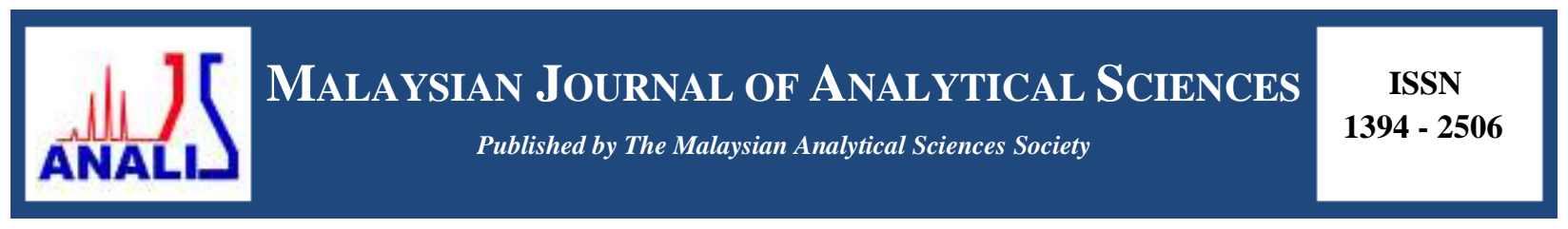

\title{
SYNTHESIS OF THIOUREA DERIVATIVES AND BINDING BEHAVIOR TOWARDS THE MERCURY ION
}

\author{
(Sintesis Sebatian Terbitan Tiourea dan Sifat Pengikatan Terhadap Ion Merkuri) \\ Fatimatul Akma Awang Ngah, Emma Izzati Zakariah, Nurul Izzaty Hassan, Bohari Yamin, Suhaila Sapari, \\ Siti Aishah Hasbullah* \\ School of Chemical Sciences and Food Technology, \\ Faculty of Science and Technology, \\ Universiti Kebangsaan Malaysia, 43600 UKM Bangi, Selangor, Malaysia \\ *Corresponding author: aishah80@ukm.edu.my
}

Received: 19 July 2017 Accepted: 30 September 2017

\begin{abstract}
Four new thiourea derivatives namely 1-(2-aminophenyl)-3-(naphthlene-1-yl)thiourea, 3a, $N$-(2-aminophenyl)- $N$-(1naphthalenyl)thiourea, 3a', 1-(3-aminophenyl)-3-(naphthalene-1-yl)thiourea, 3b, and 1,4-phenylene-bis[3-( $\alpha$-naphthyl)thiourea], 3c have been synthesized by the reaction of 1-naphthyl isothiocyanate, 1a with 1,2-phenylenediamine, 2a, 1,3phenylenediamine, $\mathbf{2 b}, 1,4$-phenylenediamine, $\mathbf{2 c}$. The binding behavior of $\mathbf{3 b}$ for mercury ion was evaluated by 'naked- eye', ${ }^{1} \mathrm{H}$ Nucleus Magnetic Resonance, Fourier Transformation Infrared, and UV-Vis titration methods. Stoichiometry of the host-guest complexation of $\mathbf{3 b}$ and mercury ion was found to be 1:1 by plotting molar-ratio curves.
\end{abstract}

Keywords: synthesis, thiourea, sensing, mercury

\section{Abstrak}

Empat sebatian baru terbitan tiourea iaitu 1-(2-aminofenil)-3-(naftil-1-il)tiourea, 3a, $N$-(2- aminofenil)- $N$-(1-naftilin-il)tiourea, 3a', 1-(3- aminofenil)-3-(naftilin-1-il)tiourea, 3b, and 1,4-fenilin-bis[3-( $\alpha$-naftil)tiourea], 3c telah berjaya disintesis melalui tindak balas di antara 1-naftil isotiosianat, 1a dengan 1,2-fenilenadiamina, 2a, dan 1,3-fenilenadiamina, 2b dan 1,4fenilenadiamina, 2c. Sifat kelakuan pengikatan sebatian $\mathbf{3 b}$ terhadap ion merkuri dikaji dengan menggunakan kaedah mata kasar, ${ }^{1} \mathrm{H}$ Resonan Magnetik Nukleus, Infra Merah Transformasi Fourier, dan juga pengtitratan Ultralembayung-Cahaya Nampak (UVVis). Stoikiometri kompleks $3 \mathrm{~b}$ dan ion merkri ditemui pada nisbah 1:1 melalui lengkung nisbah molar yang telah diplot.

Kata kunci: sintesis, tiourea, penderia, merkuri

\section{Introduction}

Thiourea, $\mathrm{SC}\left(\mathrm{NH}_{2}\right)_{2}$ is a compound that is analogous to urea $\left(\mathrm{CO}\left(\mathrm{NH}_{2}\right)_{2}\right)$, where by the oxygen atom has been replaced with a sulfur atom. It has different properties compared to urea due to the difference in electronegativity between sulfur and oxygen [1]. Thiourea is one of the most important compounds used in relation to metallic electrodes [2]. It can absorb to a metal surface and in so doing block active sites [2]. It is also one of the most important industrial chemical products [3]. The presence of heavy metal ions in the environment is a large problem due to their acute toxicity. They are not biodegradable and harmful to human organs [4]. Among the variety of metal ions, mercury is hugely harmful because its compounds are widely spread in air, soil, and water also can subsequently bio-accumulate through the food chain [5]. 
Thioureas are also selective analytical reagents, especially for the determination of metals in the presence of other metal ions [6]. Thiourea derivatives with conjugated oxygen or nitrogen donor sites represent some of the most important chelating ligands in coordination chemistry and their metal complexes are useful for homogenous catalysis, chemical vapor deposition, supramolecular chemistry, redox sensing, magnetic materials and so on [7]. Copper is one of the important trace metals and has been used in complexes to disinfect human solids, liquids and also human tissues. The high concentrations of the metals in the environment are harmful and toxic to living organisms [8]. Mercury is very hazardous to the environment and living organisms. It can exist as either an inorganic or organic species in the environment. It can pass through biological membranes and can cause many dangerous conditions like cancer, brain damage and also motion disorder [9]. The thiourea compound can bind with metal ions to make a stable complex due to the sulfur atom's excellent donor properties [10]. Moreover, it is also extremely flexible as a ligand, either neutral, mono-anion or dianions that able to bind to metal center [11]. Metal complexes of thiourea are commonly semi organic materials, in which the organic and inorganic parts of complex confer the advantageous properties of both elements [12].

Thioureas show high biological activity where they act as corrosion inhibitors and antioxidants and are also the component of polymers. In 2006, researchers reported acyl thiourea derivatives are for a wide range of biological activities like bactericidal, fungicidal, herbicidal and insecticidal also possess regulating activity for plant growth [13]. In continuation of our research theme, herein we wish to report the synthesis and characterization of four thioureas based 1,2-, 1,3- and 1,4-phenylenediamine. The binding behavior of $\mathbf{3 b}$ toward mercury ion was investigated by 'naked eyes', ${ }^{1} \mathrm{H}$ NMR, FTIR and UV-vis titration method.

\section{Chemicals}

\section{Materials and Methods}

This research was using some chemicals such as 1,2-phenylenediamine (Sigma Aldrich), 1,3-phenylenediamine (Sigma Aldrich), 1,4-phenylenediamine (Merck), 1-naphthyl isothiocyanate (Sigma Aldrich), and solvent such as dimethyl sulfoxide (DMSO) and dichloromethane (DCM) from Fisher company. All the chemicals and solvents were used directly without any purification.

\section{Physical measurement}

All reactions were performed under reflux condition. Chemicals and solvents were purchased from Sigma Aldrich and Acros and were used directly without further purification. The compound was analyzed using FTIR Perkin Elmer Model Spectrum GX in the range $400-4000 \mathrm{~cm}^{-1}$ using $\mathrm{KBr}$ method, ${ }^{1} \mathrm{H}$ and ${ }^{1} \mathrm{C}$ NMR spectrometer model Bruker Advance $400 \mathrm{MHz}$, Liquid Chromatography Mass Spectroscopy model Dionex/Bruker MicroToF Q and Ultraviolet visible (UV-vis) CARY Agilent 100.

\section{Synthesis of 1-(2-aminophenyl)-3-(naphthlene-1-yl)thiourea, 3a}

A solution of 1-naphthyl isothiocyanate $(0.185 \mathrm{~g}, 1.00 \mathrm{mmol})$ and 1,2 -phenylenediamine $(0.054 \mathrm{~g}, 0.50 \mathrm{mmol})$ in $10 \mathrm{~mL}$ dichloromethane (DCM) was refluxed for 23 hours. The white precipitate was filtered out and the pure product was isolated $(63 \%, 0.092 \mathrm{~g})$.

\section{Synthesis of N-(2-aminophenyl)-N-(1-naphthalenyl)thiourea, 3a'}

A solution of 1-naphthyl isothiocyanate $(0.093 \mathrm{~g}, 0.025 \mathrm{mmol})$ and 1-(2-aminophenyl)-3-(naphthlene-1-yl)thiourea (3a) $(0.073 \mathrm{~g}, 0.025 \mathrm{mmol})$ in $20 \mathrm{~mL}$ DCM was refluxed for 24 hours. The white precipitate was filtered, and the pure product was isolated $(85 \%, 0.010 \mathrm{~g})$.

\section{Synthesis of 1-(3-aminophenyl)-3-(naphthalene-1-yl)thiourea, 3b}

A solution of 1-naphthyl isothiocyanate $(0.705 \mathrm{~g}, 2.00 \mathrm{mmol})$ and 1,3 -phenylenediamine $(0.109 \mathrm{~g}, 1.00 \mathrm{mmol})$ in $20 \mathrm{~mL}$ dichloromethane (DCM) was refluxed for 24 hours. The white precipitate was filtered out and the pure product was isolated $(82 \%, 0.241 \mathrm{~g})$. 


\section{Synthesis of 1,4-phenylene-bis[3-( $\alpha$-naphthyl)thiourea], $3 \mathrm{c}$}

A solution of 1-naphthyl isothiocyanate $(0.927 \mathrm{~g}, 5.00 \mathrm{mmol})$ and 1, 4-phenylenediamine $(0.270 \mathrm{~g}, 2.50 \mathrm{mmol})$ in $20 \mathrm{~mL}$ dichloromethane (DCM) was refluxed for 28 hours. The white precipitate was filtered out and the pure product was isolated $(95 \%, 1.136 \mathrm{~g})$.

\section{Binding behaviors for compound $3 \mathrm{~b}$ towards selected metal salts}

The binding experiments were carried out using naked-eye method, FTIR, UV-Vis titration and ${ }^{1} \mathrm{H}$ NMR titration. For naked-eye detection, stock solutions $\left(1 \times 10^{-3} \mathrm{M}\right)$ of $\mathrm{Fe}^{2+}, \mathrm{Pb}^{2+}, \mathrm{Hg}^{2+}, \mathrm{Ni}^{2+}, \mathrm{Zn}^{2+}, \mathrm{Ag}^{+}, \mathrm{Cu}^{2+}, \mathrm{Sn}^{2+}$ ions and compound $\mathbf{3 b}$ in dimethyl sulfoxide (DMSO) were prepared. $1.0 \mathrm{ml}$ vial containing $\mathrm{Fe}^{2+}$ and $1.0 \mathrm{ml}$ of $\mathbf{3 b}$ was mixed together in vials and shaken to ensure homogeneity. The color changes were observed and the data were collected. The experiment was repeated using $\mathrm{Pb}^{2+}, \mathrm{Hg}^{2+}, \mathrm{Ni}^{2+}, \mathrm{Zn}^{2+}, \mathrm{Ag}^{+}, \mathrm{Cu}^{2+}, \mathrm{Sn}^{2+}$ ions.

For UV-Vis titrations, $10 \mathrm{ml}$ stock solutions $\left(1 \times 10^{-3} \mathrm{M}\right)$ of $\mathbf{3 b}$ and selected metal ions $\left(1 \times 10^{-3} \mathrm{M}\right)$ were prepared in DMSO as solvent. The screening of these solutions was conducted on a UV-Vis spectrophotometer. $200 \mu \mathrm{L}$ of $\mathbf{3 b}$ and $0-600 \mu \mathrm{L}$ of the mercury ion solution were titrated and directly analyzed using UV-Vis spectrophotometer [5].

For the ${ }^{1} \mathrm{H}$ NMR titrations, $300 \mu \mathrm{L}$ of a stock solution of $\mathrm{Hg}^{2+}(0-0.06 \mathrm{M})$ was added into $560 \mu \mathrm{L}$ of stock solution of $3 \mathbf{b}(0.03 \mathrm{M})$ and then was placed in an NMR tube. Both of solutions were in DMSO- $d_{6}$. The titration solutions were analyzed using ${ }^{1} \mathrm{H}$ NMR spectroscopy [14].

For analysis using FTIR spectroscopy, the sample was prepared by using $0.03 \mathrm{M}$ of compound $\mathbf{3 b}$ and $0.03 \mathrm{M}$ of $\mathrm{Hg}(\mathrm{OAc})_{2}$, both in DMSO as solvent.

\section{Results and Discussion}

Compound 3a, 3a', 3b and $\mathbf{3 c}$ were synthesized by the reaction of ethyl isothiocyanate $\mathbf{1 a}$ with diamines $\mathbf{2 a}, \mathbf{2 b}$ and 2c (Scheme 1).

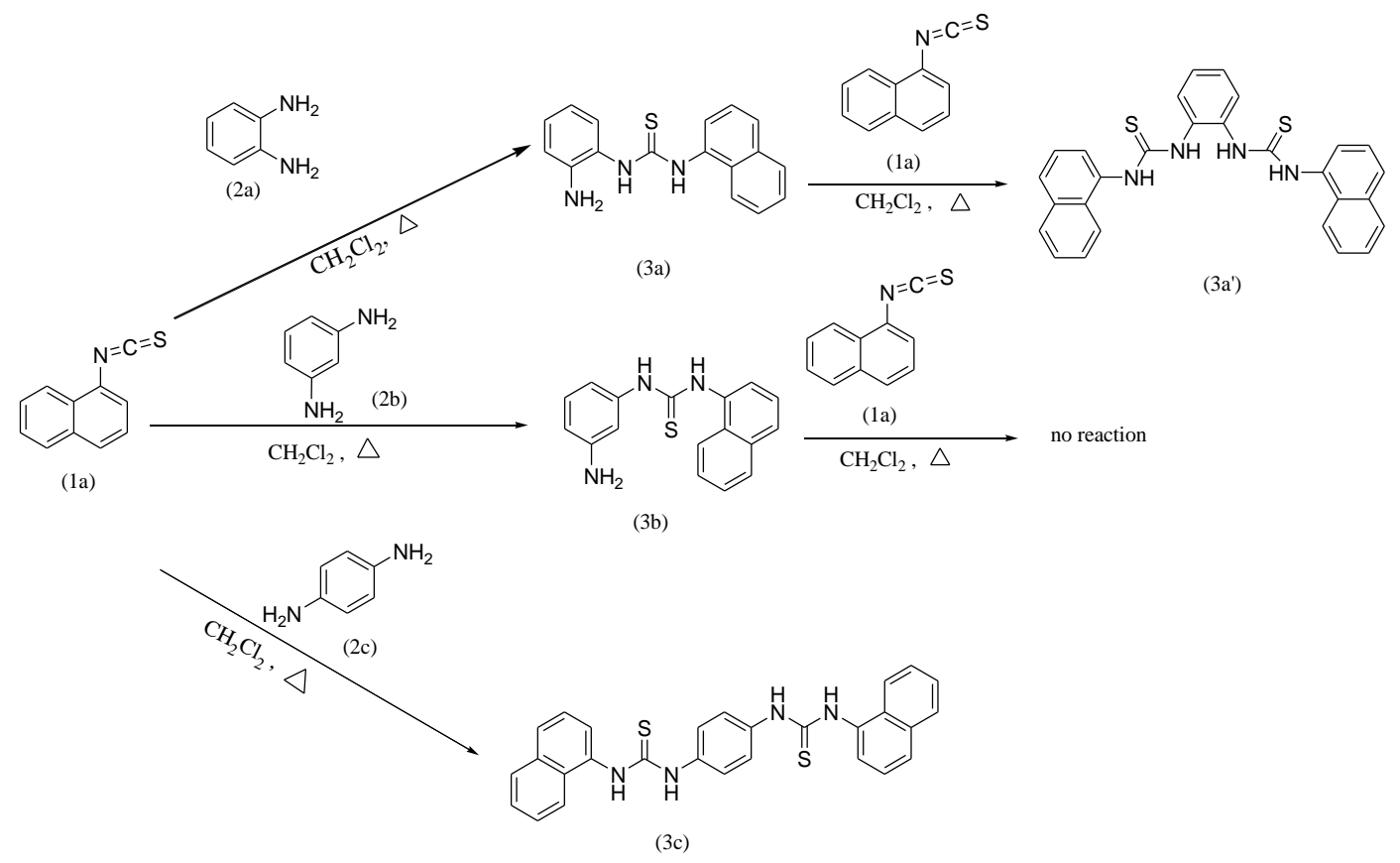

Scheme 1. Reaction schemes for synthesis of compounds $\mathbf{3 a}, \mathbf{3 a}, \mathbf{3} \mathbf{b}$ and $\mathbf{3 c}$ 
Fatimatul Akma et al: SYNTHESIS OF THIOUREA DERIVATIVES AND BINDING BEHAVIOR TOWARDS

THE MERCURY ION

1-(2-aminophenyl)-3-(naphthlene-1-yl)thiourea, 3a

Mp: $164.0-168.1{ }^{\circ} \mathrm{C}$. IR (KBr pellet) $v\left(\mathrm{~cm}^{-1}\right): 3467,3358,3313,3145,3135,2970,1595,1508,1284,747 .{ }^{1} \mathrm{H}$ RMN (DMSO- $\left.d_{6}, 400 \mathrm{MHz}\right) \delta(\mathrm{ppm}): 9.62(\mathrm{~s}, 1 \mathrm{H}, \mathrm{N} H), 7.21(\mathrm{~s}, 1 \mathrm{H}, \mathrm{NH}), 8.01(\mathrm{dd}, 2 \mathrm{H}, \mathrm{J}=7.6 \mathrm{~Hz}$ and $7.2 \mathrm{~Hz}, \mathrm{Ar}-$ $H), 7.84(\mathrm{~d}, 1 \mathrm{H}, \mathrm{J}=8.0 \mathrm{~Hz}, \operatorname{Ar}-H), 7.53(\mathrm{~m}, 4 \mathrm{H}, \mathrm{Ar}-H), 7.11(\mathrm{~d}, 1 \mathrm{H}, \mathrm{J}=7.2 \mathrm{~Hz}, \operatorname{Ar}-H), 6.99$ (t, $1 \mathrm{H}, \mathrm{J}=8.0 \mathrm{~Hz}, \mathrm{Ar}-H)$, $6.77(\mathrm{~d}, 1 \mathrm{H}, \mathrm{J}=7.6 \mathrm{~Hz}, \mathrm{Ar}-\mathrm{H}), 6.60(\mathrm{t}, 1 \mathrm{H}, \mathrm{J}=7.2 \mathrm{~Hz}, \mathrm{Ar}-H), 4.93\left(\mathrm{~s}, 2 \mathrm{H}, \mathrm{NH}_{2}\right) .{ }^{13} \mathrm{C}$ RMN (DMSO- $\left.d_{6}, 100 \mathrm{MHz}\right) \delta$ (ppm): $182.1(C=\mathrm{S}), 144.6(\mathrm{Ar}-\mathrm{C}), 135.6(\mathrm{Ar}-C), 134.3(\mathrm{Ar}-\mathrm{C}), 127.9(\mathrm{Ar}-C), 124.6(\mathrm{Ar}-C), 130.5(\mathrm{Ar}-\mathrm{CH}), 128.9$ $(\mathrm{Ar}-\mathrm{CH}), 128.5(\mathrm{Ar}-\mathrm{CH}), 127.2(\mathrm{Ar}-\mathrm{CH}), 126.6(\mathrm{Ar}-\mathrm{CH}), 126.5(\mathrm{Ar}-\mathrm{CH}), 126.1(2 \times \mathrm{Ar}-\mathrm{CH}), 123.5(\mathrm{Ar}-\mathrm{CH}), 117.0$ $(\mathrm{Ar}-\mathrm{CH}), 116.4(\mathrm{Ar}-\mathrm{CH})$. LC-MS (ESI) m/z: calculated for $\mathrm{C}_{17} \mathrm{H}_{15} \mathrm{~N}_{3} \mathrm{~S}$ (293.39), found (M-H $\mathrm{H}^{+}$) (292.08) [15].

\section{N-(2-aminophenyl)-N-(1-naphthalenyl)thiourea, 3a'}

Mp: 165.0 - $169.8^{\circ} \mathrm{C}$. IR (KBr pellet) $v\left(\mathrm{~cm}^{-1}\right): 3457,3307,3129,2958,1525,1500,1251,752 .{ }^{1} \mathrm{H}$ NMR (DMSO$\left.\mathrm{d}_{6}, 400 \mathrm{MHz}\right) \delta(\mathrm{ppm}): 10.14(\mathrm{~s}, 1 \mathrm{H}, \mathrm{NH}), 9.27(\mathrm{~s}, 1 \mathrm{H}, \mathrm{NH}), 8.01(\mathrm{~m}, 3 \mathrm{H}, \mathrm{Ar}-H), 7.88(\mathrm{~d}, 1 \mathrm{H}, \mathrm{J}=8.0 \mathrm{~Hz}, \mathrm{Ar}-H), 7.56$ $(\mathrm{t}, 3 \mathrm{H}, \mathrm{J}=4.0 \mathrm{~Hz}, \mathrm{Ar}-H), 7.48(\mathrm{~d}, 2 \mathrm{H}, \mathrm{J}=3.6 \mathrm{~Hz}, \mathrm{Ar}-H) .{ }^{13} \mathrm{C}$ NMR (DMSO-d $\left.6,100 \mathrm{MHz}\right) \delta(\mathrm{ppm}): 182.1(C=\mathrm{S})$, 144.6, 134.3, 130.5, 123.5 (4 Ar-C), 128.9, 128.5, 127.9, 127.2, 126.6, 126.5, 126.1, 117.0, 116.4 (9 Ar-CH). LCMS (ESI) m/z: calculated for $\mathrm{C}_{28} \mathrm{H}_{22} \mathrm{~N}_{4} \mathrm{~S}_{2}$ (478.63), found (477.10).

\section{1-(3-aminophenyl)-3-(naphthalene-1-yl)thiourea, 3b}

Mp: $117.4-121.8^{\circ} \mathrm{C}$. IR (KBr pellet) $v\left(\mathrm{~cm}^{-1}\right): 3433,3345,3322,3207,3043,1595,1519,1225$, and $775 .{ }^{1} \mathrm{H}$ RMN $\left(\right.$ DMSO- $\left.d_{6}, 400 \mathrm{MHz}\right) \delta(\mathrm{ppm}): 9.62(\mathrm{~d}, 2 \mathrm{H}, \mathrm{J}=5.2 \mathrm{~Hz}, \mathrm{NH}), 7.94(\mathrm{~s}, 1 \mathrm{H}, \mathrm{Ar}-H), 7.84(\mathrm{~d}, 1 \mathrm{H}, \mathrm{J}=8 \mathrm{~Hz}, \mathrm{Ar}-H), 7.52$ $(\mathrm{m}, 4 \mathrm{H}, \mathrm{J}=8,4 \mathrm{~Hz}, \mathrm{Ar}-H), 6.99(\mathrm{t}, 1 \mathrm{H}, \mathrm{J}=8 \mathrm{~Hz}, \mathrm{Ar}-H), 6.65(\mathrm{~d}, 1 \mathrm{H}, \mathrm{J}=8 \mathrm{~Hz}, \mathrm{Ar}-H), 6.78(\mathrm{~s}, 1 \mathrm{H}, \mathrm{Ar}-H), 6.39(\mathrm{~d}$, $1 \mathrm{H}, \mathrm{J}=8 \mathrm{~Hz}, \mathrm{Ar}-H), 5.12\left(\mathrm{~s}, 2 \mathrm{H}, \mathrm{NH}_{2}\right) .{ }^{13} \mathrm{C}$ RMN (DMSO- $\left.d_{6}, 100 \mathrm{MHz}\right) \delta(\mathrm{ppm}): 181.3(\mathrm{C}=\mathrm{S}), 149.4(\mathrm{Ar}-\mathrm{C}), 140.2$ (Ar-C), 135.7 (Ar-C), $123.5(\mathrm{Ar}-C), 111.4(\mathrm{Ar}-\mathrm{C}), 134.3(\mathrm{Ar}-\mathrm{CH}), 130.5(\mathrm{Ar}-\mathrm{CH}), 129.4(\mathrm{Ar}-\mathrm{CH}), 128.5(\mathrm{Ar}-\mathrm{CH})$, 127.1 (Ar- $\mathrm{CH}), 126.6(\mathrm{Ar}-\mathrm{CH}), 126.5(\mathrm{Ar}-\mathrm{CH}), 126.0(\mathrm{Ar}-\mathrm{CH}), 126.0(\mathrm{Ar}-\mathrm{CH}), 112.3(\mathrm{Ar}-\mathrm{CH}), 110.1(\mathrm{Ar}-\mathrm{CH})$. LC-MS (ESI) m/z: calculated for $\mathrm{C}_{17} \mathrm{H}_{15} \mathrm{~N}_{3} \mathrm{~S}\left(\mathrm{M}+\mathrm{H}^{+}\right.$) (293.39), found (294.10) [16].

\section{1,4-phenylene-bis[3-( $\alpha$-naphthyl)thiourea], $3 \mathrm{c}$}

Mp: $214.3-219.1^{\circ} \mathrm{C}$. IR (KBr pellet) $v\left(\mathrm{~cm}^{-1}\right): 3325,3186,3000,1542,1499,1221,767 .{ }^{1} \mathrm{H}$ RMN (DMSO-d 6,400 MHz) $\delta(\mathrm{ppm}): 9.87(\mathrm{~s}, 1 \mathrm{H}, \mathrm{NH}), 9.77(\mathrm{~s}, 1 \mathrm{H}, \mathrm{NH}), 7.98(\mathrm{t}, 2 \mathrm{H}, \mathrm{J}=8.0 \mathrm{~Hz}, \mathrm{Ar}-H), 7.86(\mathrm{~d}, 1 \mathrm{H}, \mathrm{J}=6.8 \mathrm{~Hz}, \mathrm{Ar}-H)$, $7.55(\mathrm{~m}, 6 \mathrm{H}, \mathrm{Ar}-H) .{ }^{13} \mathrm{C}$ RMN (DMSO-d 6 , $\left.100 \mathrm{MHz}\right) \delta(\mathrm{ppm}): 181.6(C=\mathrm{S}), 136.5(\mathrm{Ar}-C), 135.5(\mathrm{Ar}-C), 134.3(\mathrm{Ar}-$ C), $124.7(\mathrm{Ar}-\mathrm{C}), 130.4(\mathrm{Ar}-\mathrm{CH}), 128.6(\mathrm{Ar}-\mathrm{CH}), 127.2(\mathrm{Ar}-\mathrm{CH}), 126.6(\mathrm{Ar}-\mathrm{CH}), 126.5(\mathrm{Ar}-\mathrm{CH}), 126.1(\mathrm{Ar}-\mathrm{CH})$, $125.8(\mathrm{Ar}-\mathrm{CH}), 124.6(\mathrm{Ar}-\mathrm{CH}), 123.5(\mathrm{Ar}-\mathrm{CH})$. LC-MS (ESI) m/z: calculate for $\mathrm{C}_{28} \mathrm{H}_{22} \mathrm{~N}_{4} \mathrm{~S}_{2}\left(\mathrm{M}+\mathrm{H}^{+}\right)(478.63)$, found (479.1) [17].

\section{Binding behaviors for $3 \mathrm{~b}$ towards some selected metal ions}

For the visible observations, the most remarkable color change was observed in the presence of $\mathrm{Hg}^{2+}, \mathrm{Cu}^{2+}, \mathrm{Fe}^{2+}$, and $\mathrm{Ag}^{+}$ions. The color changes before and after adding the metal salts into a solution of $\mathbf{3 b}$ are seen in Figure 1 and Table 1. Based on the observation, the colorless solution became dark brown upon the addition of $\mathrm{Hg}^{2+}$ (with acetate as counter ion). Next, the screening of $\mathbf{3 b}$ with some selected metals in $2.0 \mathrm{ml}$ solvent was carried out using UV-Vis spectroscopy (Figure 2). Based on the screening, $\mathrm{Hg}^{2+}$ was found to show the highest absorption at $260 \mathrm{~nm}$, together with new bands appearing at $305 \mathrm{~nm}$ and $370 \mathrm{~nm}$ which indicated strong binding behavior of $\mathbf{3 b}$ towards the $\mathrm{Hg}^{2+}$ ion. Due to this high affinity, the $\mathrm{Hg}^{2+}$ ion was chosen for further titration studies using UV-vis and ${ }^{1} \mathrm{H}$ NMR titrations. 


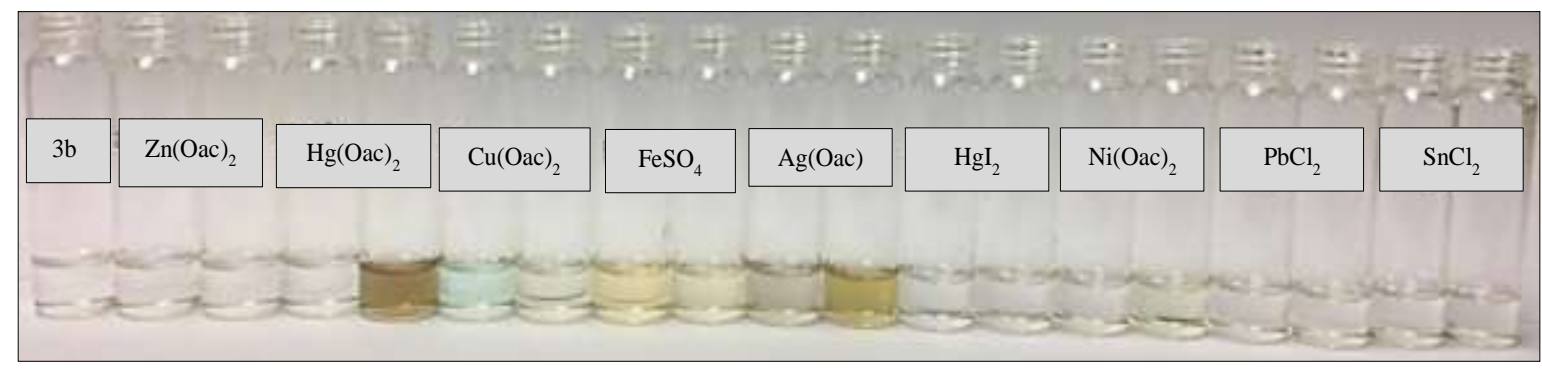

Figure 1. Color changes for naked-eyes sensor of 1-(3-aminophenyl)-3-(naphthalene-1-yl)thiourea, $\mathbf{3 b}\left(1 \times 10^{-3} \mathrm{M}\right)$ towards selected metals $\left(1 \times 10^{-3} \mathrm{M}\right)$

Table 1. Color changes before and after adding the metal salts solution into the 1-(3-aminophenyl)-3(naphthalene-1-yl)thiourea, 3b solution

\begin{tabular}{|c|c|}
\hline Metal salts & $\begin{array}{c}\text { 1-(3-aminophenyl)-3-(naphthalene-1-yl)thiourea, 3b } \\
\text { (colorless) }\end{array}$ \\
\hline $\mathrm{Zn}(\mathrm{OAc})_{2}$ (colorless) & Unchanged \\
\hline $\mathrm{Hg}(\mathrm{OAc})_{2}$ (colorless) & Dark brown \\
\hline $\mathrm{Cu}(\mathrm{OAc})_{2}$ (blue) & Light yellow \\
\hline $\mathrm{FeSO}_{4}$ (yellowish) & Light yellow \\
\hline $\mathrm{Ag}(\mathrm{OAc})$ (light grey) & Brown \\
\hline $\mathrm{HgI}_{2}$ (colorless) & Unchanged \\
\hline $\mathrm{Ni}(\mathrm{OAc})_{2}$ (colorless) & Very light yellow \\
\hline $\mathrm{PbCl}_{2}$ (colorless) & Unchanged \\
\hline $\mathrm{SnCl}_{2}$ (colorless) & Unchanged \\
\hline
\end{tabular}

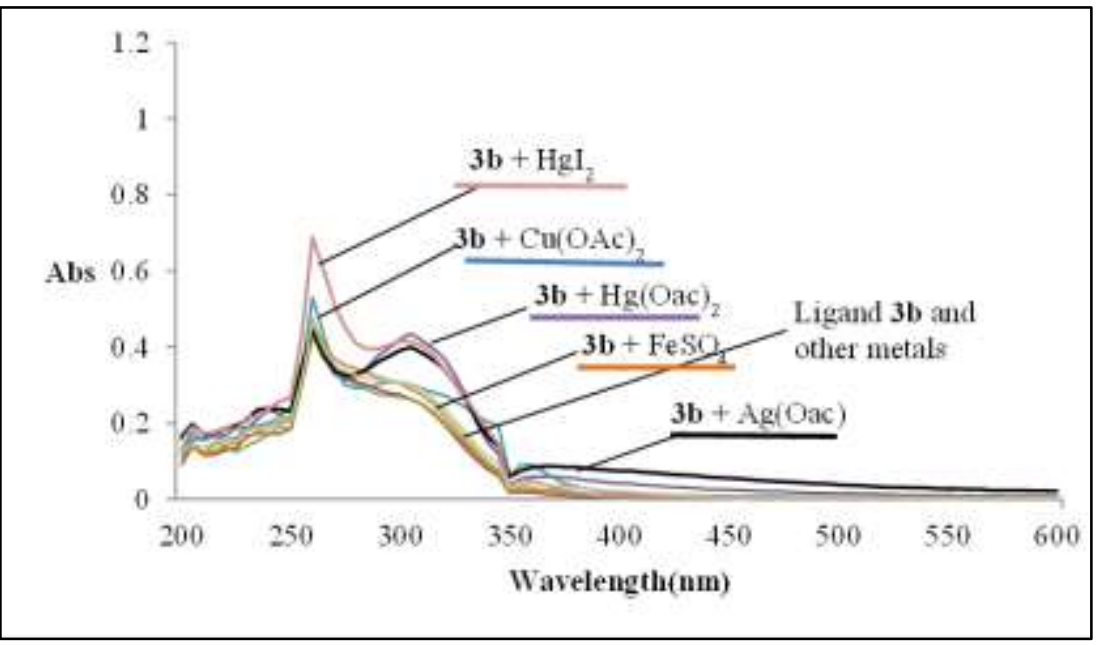

Figure 2. UV-Vis spectra of $\mathbf{3 b}\left(1 \times 10^{-3} \mathrm{M}\right)$ with all metal ions $\left(1 \times 10^{-3} \mathrm{M}\right)$ in DMSO as solvent 
The titration studies of $\mathbf{3 b}$ toward $\mathrm{Hg}^{2+}$ ions were performed in DMSO. Figure 3 shows that upon the gradual addition of $25 \mu \mathrm{L}$ equivalent of $\mathrm{Hg}^{2+}\left(1 \times 10^{-3} \mathrm{M}\right)$ to the $200 \mu \mathrm{L}$ ligand solution $\left(1 \times 10^{-3} \mathrm{M}\right)$, new absorption bands at $305 \mathrm{~nm}$ and $370 \mathrm{~nm}$ appeared with increasing intensity. The absorbance maxima increased linearly with the concentration of $\mathrm{Hg}^{2+}$ in a range of $0-1.0 \mathrm{M}$ with a correlation coefficient of 0.99306 (Figure 4) after 10 readings. There was an isosbestic point at $280 \mathrm{~nm}$ which indicated that there were only two species present at equilibrium [18]. In addition, a new shoulder band appeared at $345 \mathrm{~nm}$, something which relates to the intramolecular charge transfer (ICT) on the thiourea moiety of compound $\mathbf{3 b}$. The band at $370 \mathrm{~nm}$ shows a hyperchromic effect with an increasing amount of $\mathrm{Hg}^{2+}$. Based on the UV-Vis titration, we were able to calculate the stoichiometry of the binding interaction between ligand $\mathbf{3 b}$ and $\mathrm{Hg}^{2+}$ through the molar-ratio curve method (Figure 4) [19]. The binding ratio of $\mathbf{3 b}-\mathrm{Hg}^{2+}$ was $1: 1$ and the binding constant $\left(\mathrm{K}_{\mathrm{d}}\right)$ was calculated using the nonlinear regression equation using Sigma Plot 12.0 software. The $\mathrm{K}_{\mathrm{d}}$ value of $\mathbf{3 b}-\mathrm{Hg}^{2+}$ was $1.659 \mathrm{M}$.

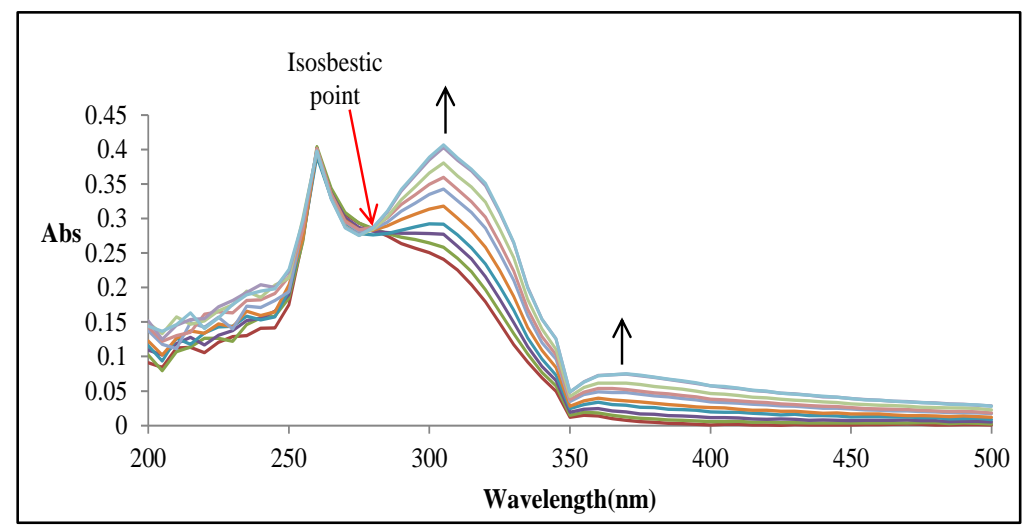

Figure 3. Changes in absorption spectra of $\mathbf{3 b}\left(1 \times 10^{-3} \mathrm{M}\right)$ with increasing amount of $\mathrm{Hg}^{2+}$ ions $\left(\mathrm{Hg}(\mathrm{OAc})_{2}\right)$ $\left(1 \times 10^{-3} \mathrm{M}\right)$

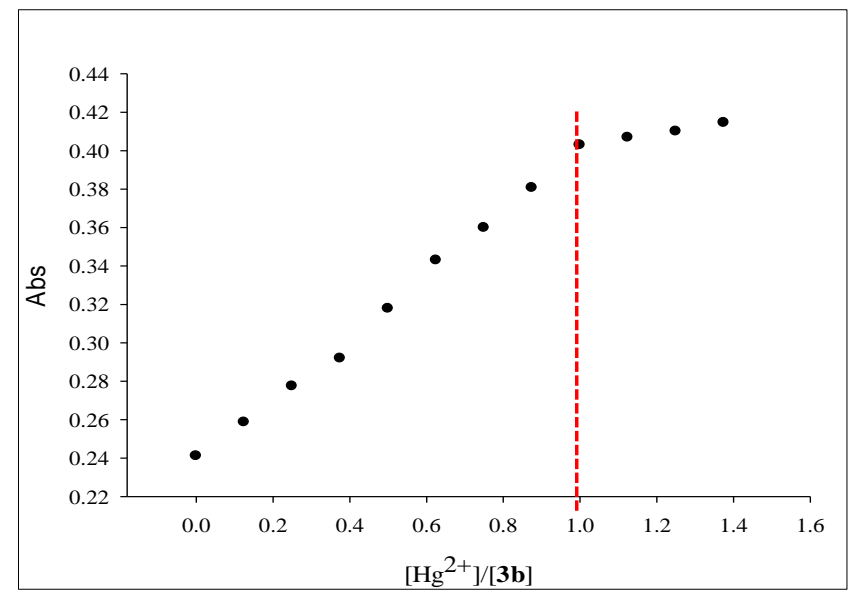

Figure 4. Variation of absorbance at $305 \mathrm{~nm}$ versus $\left[\mathrm{Hg}^{2+}\right] /[\mathbf{3 b}]$

To further study the binding behavior, ${ }^{1} \mathrm{H}$ NMR titrations were performed in DMSO- $\mathrm{d}_{6}$ (Figure 5). Protons for the two NH of compound $\mathbf{3 b}$ were observed at $9.61 \mathrm{ppm}$ and $9.59 \mathrm{ppm}$ respectively. The integral of the peaks were both 2.00. After gradually adding the $\mathrm{Hg}^{2+}$ solution $(0-0.06 \mathrm{M})$, the size of the signals decreased and their integration value became less than 1 . This was due to the strong interaction between $\mathbf{3 b}$ and $\mathrm{Hg}^{2+}$. In addition, the protons for 
the $\mathrm{NH}_{2}$ groups in the original spectra for compound $\mathbf{3 b}$ were singlet, but in combination with $\mathrm{Hg}^{2+}$ solution, the signal became broader and less intense (integration less than 1.00).

Next, the FTIR spectrum showed that the complex of $\mathbf{3 b}$ and $\mathrm{Hg}^{2+}$ showed a decreased intensity for both the CN and $\mathrm{C}=\mathrm{S}$ groups, whilst a new peak appeared at $998 \mathrm{~cm}^{-1}$ (Figure 6) [20]. This peak was due to the complexation of the $\mathrm{Hg}^{2+}$ ion and the thiourea moiety. The peaks responsible for the $\mathrm{NH}_{2}$ region disappeared due to the intramolecular charge transfer formed with the thiourea moiety. The proposed reaction mechanism of the $\mathbf{3 b}-\mathrm{Hg}$ interaction is shown in Figure 7.

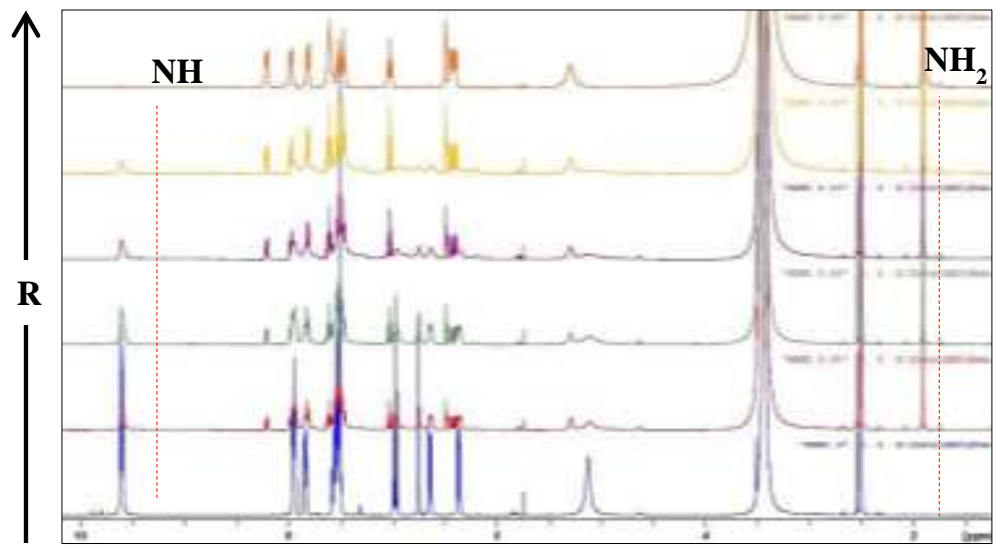

Figure 5. ${ }^{1} \mathrm{H}$ NMR titration of $\mathbf{3 b}$ showing changes in the $\mathrm{NH}$ and $\mathrm{NH}_{2}$ chemical shifts of the receptor $\mathbf{3 b}(0.03 \mathrm{M})$ with increasing amount of $\mathrm{Hg}^{2+}(\mathbf{R})(0-0.06 \mathrm{M})$ in DMSO- $d_{6}$

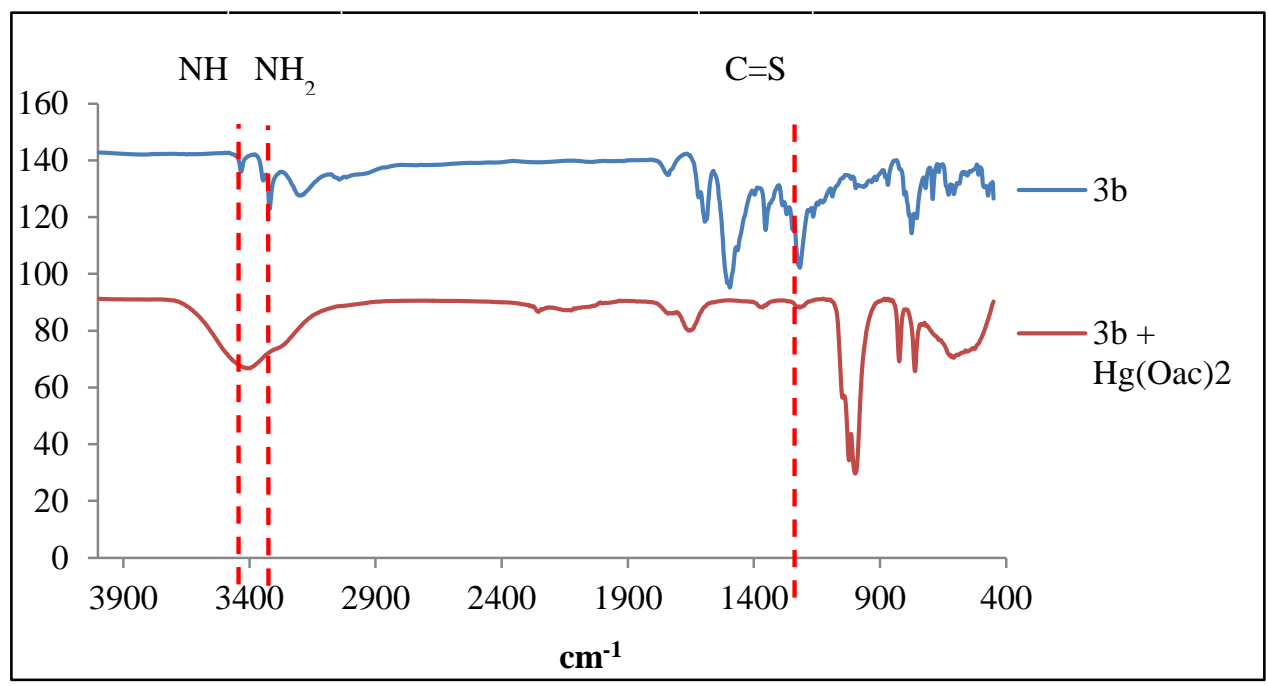

Figure 6. FTIR spectrum of compound $\mathbf{3 b}$ with $\mathrm{Hg}(\mathrm{OAc})_{2}$ solution. 


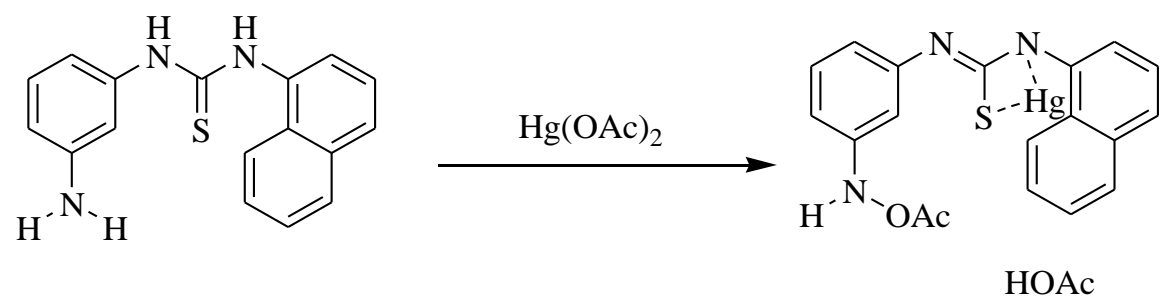

Figure 7. The proposed reaction mechanism of the $\mathbf{3 b - H g}$ interactions

\section{Conclusion}

In conclusion, we have reported the synthesis of thiourea derivatives, 1-(2-aminophenyl)-3-(naphthlene-1-yl) thiourea (3a), N-(2-aminophenyl)-N-(1-naphthalenyl)thiourea (3a'), 1-(3-aminophenyl)-3-(naphthalene-1-yl) thiourea (3b), and 1,4-phenylene-bis[3-( $\alpha$-naphthyl)thiourea] (3c). Using observation by naked eye, UV-vis titration, FTIR, and ${ }^{1} \mathrm{H}$ NMR titration methods showed that the binding behavior of compound $\mathbf{3 b}$ towards $\mathrm{Hg}^{2+}$ afforded a complex with a 1:1 binding ratio. Future work will be aimed at using compound $\mathbf{3 b}$ for sensor based applications whereby the fate of $\mathrm{Hg}^{2+}$ can be tracked in the environment.

\section{Acknowledgement}

The authors thank the Ministry of Higher Education Malaysia for My Master Scholarship, School of Chemical Sciences and Food Technology, National University of Malaysia, Center for Research and Instrumentation (CRIM), Research Grant GUP-2017-086 and everyone that involved in this research.

\section{References}

1. Alkherraz, A. M., Lusta, I. Z. and Zubi, E. A. (2014). Synthesis and use of thiourea derivative (1-phenyl-3benzoyl-2-thiourea) for extraction of cadmium ion. International Scholarly and Scientific Research \& Innovation, 8(2): $116-118$.

2. Zhao, J. and Cui, G. (2011). Study on adsorption and complexation behavior of thiourea on copper surface. International Journal of Electrochemical Science, 6: 4048 - 4058.

3. Yahyazahed, A. and Ghasemi, Z. (2013). Synthesis of unsymmetrical thiourea derivatives. European Chemical Bulletin, 2(8): $573-575$.

4. Zhang, Z., Lu, S., Sha, C. and Xu, D. (2015). A single thiourea-appended 1,8-naphthalimide chemosensor for three heavy metal ions: $\mathrm{Fe}^{3+}, \mathrm{Pb}^{2+}$, and $\mathrm{Hg}^{2+}$. Sensors and Actuators, 208: 258 - 266.

5. Khansari, M. E., Wallace, K. D. and Hossain, M. A. (2013). Synthesis and anion recognition studies of dipodal thiourea-based sensor for anions. Tetrahedron Letters, 55: 438 - 440.

6. Singh, A., Bharty, M. K., Bharati, P., Bharti, A., Singh, S. and Singh, N. K. (2015). Synthesis, spectral, thermal and structural characterization of a hexanuclear copper(I) cluster and a cobalt(III) complex of 1-ethyl-3-phenylthiourea. Polyhedron, 85: 918 - 925.

7. Saad, F. A. (2014). Coordination chemistry of some first row transition metal complexes with multi-dentate ligand (1- benzoyl - 3-(4-methylpyridin -2-yl) thiourea), spectral, electrochemical and $\mathrm{x}$ - ray single crystal studies. International Journal of Electrochemical Science, 9: 4761 - 4775.

8. Rauf, M. K., Imtiaz-ud-Din, Badshah, A., Gielen, M., Ebihara, M., de Vos, D. and Ahmed, S. (2009). Synthesis, structural characterization and in vitro cytotoxicity and anti-bacterial activity of some copper(I) complexes with N,N'-disubstituted thioureas. Journal of Inorganic Biochemistry, 103: 1135 - 1144.

9. Lee, J. Y., Rao, B. A., Hwang, J. Y. and Son, Y. (2015). A novel sensing capabilities and structural modification from thiourea to urea derivative by $\mathrm{Hg}\left(\mathrm{ClO}_{4}\right)_{2}$ : Selective dual chemodosimeter for $\mathrm{Hg}^{2+}$ and $\mathrm{F}$ ions. Sensors and Actuators B, 220: 1070 - 1085.

10. Arslan, H., Duran, N., Borekci, G., Koray, O. and Akbay, C. (2009). Antimicrobial activity of some thiourea derivatives and their nickel and copper complexes. Molecules, 14: $519-522$. 
11. Saeed, A., Abbas, N., Ashraf, Z. and Bolte, M. (2013). Synthesis, characterization and antibacterial activity of new 1,2- and 1,4-bis(n'-substituted thioureido)benzene derivatives. South African Journal of Chemistry, 66: 273 -278 .

12. Kumari, R. G., Ramakrishnan, V., Carolin, M. L., Kumar, J., Sarua, A. and Kuball, M. (2009). Raman spectral investigation of thiourea complexes. Spectrochimica Acta Part A, 73: 263 - 267.

13. Ke, S. Y. and Xue, S. J. (2006). Synthesis and herbicidal activity of n-(o-fluorophenoxyacetyl)thioureas derivatives and related fused heterocyclic compounds. Arkivoc, 10: 63 - 68 .

14. Odago, M. O., Colabello, D. M. and Lees, A. J. (2010). A simple thiourea based colorimetric sensor for cyanide anion. Tetrahedron Letters, 66: 7465 - 7471.

15. Perry, C. J., Holding, K. and Tyrrell, E.. (2008). Simple, novel synthesis for 1-carbamoyl-1H-benzotriazole and some of its analogs. Synthetic Communications, 38: $3354-3365$.

16. Awang Ngah, F. A., Lee, Y. H., Hasbullah, S. A. and Hassan, N. I. (2016). Synthesis and characterization of 1 (3-aminophenyl)-3-(naphthalen-1-yl)thiourea and preliminary study towards binding with metal ions. AIP Conference Proceedings, 1784 (1): 1 - 8.

17. Zhang, L. P., Shang, X. B., Wu, Q. F., Zhang, Y. and Li, J. P. (2012). Highly efficient method for the synthesis of 1,4-phenylenedithioureas under solvent- and catalyst- free condition promoted by microwave irradiation. International Journal of Rapid Communication of Synthetic Organic Chemistry, 42 (7): 1045 - 1052.

18. Kang, J., Lee, J. H., Kim, Y. H., Lee, S. K., Kim, E. Y., Lee, H. G. and Kim, C. (2011). Simple urea/thiourea sensors for the biologically important ions. Journal of Inclusion Phenomena and Macrocyclic Chemistry, 70: $29-35$.

19. Fakhar, I., Yamin, B. and Hasbullah, S.A. (2017). A comparative study of the metal binding behavior of alanine based bis-thiourea isomers. Chemistry Central Journal, 11:76. $1-16$.

20. Wiles, D. M., Gingras, B. A. and Suprunchuk, T. (1966). The C=S stretching vibration in the infrared spectra of some thiosemicarbazones. Canadian Journal of Chemistry, 45: 469 - 473. 